\title{
Implementation Result of Basic Tiered Training based Competence by Early Childhood Tutor in Early Childhood Learning Process
}

\author{
Lulu Yuliani \\ Department Non-formal education \\ Universitas Pendidikan Indonesia \\ Bandung, Indonesia \\ lulululu@student.upi.edu
}

\begin{abstract}
The aims of the research is to know the implementation result of basic tiered training based competence for Tutor PAUD in early childhood learning process that was held by HIMPAUDI in Tasikmalaya. The research uses qualitative approach with grounded theory method. Based on data analysis and research findings there are The Implementation of basic tiered training is quite good signed by the planning of basic tiered training referred to the 2015 training guide. The Preparation of Lesson plans in which the tutor can make daily and weekly learning plan better than before. The implementation of early childhood learning strategy in which PAUD Ihya Assunnah used Beyond Circle and Center method meanwhile PAUD Ghifari used Singing Method. The assessment of early childhood learning by direct observation through seeing each children development objectively. The participant of the research consists of 7 people including the base informant and source informant. The implementation of basic tiered training result based competence by Early Childhood Tutor succeeded developing the aims of development aspect, got positive result proving that basic tiered training they followed could improve early childhood learning process.
\end{abstract}

Keywords-Implementation of Tiered Training-Based Competence

\section{INTRODUCTION}

The education sector has now reached its real globalization era. Information and communication grow rapidly result in high competition. Teaching and learning process is not mere rote but also training the children to think, to do, and to be (UNESCO, 2013). In order to realize it, education in Indonesia extremely need an adequate, qualified, and professional teaching workforce besides able to compete in regional, national and international forum.

Teacher (in this article called TUTOR) is one of determinant factor in educational success. Tutor's role becomes very important. Early Childhood Tutor Task is very noble and need special attention and patient so it takes optimal performance. Many problematic and polemic faced by early childhood tutor is associated with duties and great responsibilities to early childhood education. There are two basic factors which influence tutor's performance as individual teacher.
Based on identification of problem above the main problem of this research can be formulated as How is the implementation of basic tiered training result which have been implemented by Early Childhood Teacher's Association (HIMPAUDI) in Tasikmalaya.

The aims of the research are to know the implementation result of basic tiered training based competence for Tutor PAUD in early childhood learning process that was held by HIMPAUDI in Tasikmalaya.

Simamora [1] stated that training is a series activities which set to improve several skill, knowledge, experience, or individual behavior. Meanwhile based on Presidential Decree No. 15 of 1974 the training means as the following:

Training is a part of education that involves learning process to acquire and improve skills outside the education system in force in relatively short time and by using the method that is more about practice than theory.

Kamil, M [2] formulated the meaning of training as below: Training is a process of deliberate or planned, not activities that are accidental or spontaneous. Training is a process that consists of a series of planned and systematic activities that focused on a goal. This training is well organized related to the needs of workforce and in a wider community.

Waterson [3] in Sudjana [3] explained that the essence of planning is a conscious effort, organized, and ongoing performed to select the best alternative from a number of alternative measures to achieve the goal. A planning is not a separate activity but is a part of complex decision-making process. In addition, Schaffer [4] in Sudjana [4] stated that if we talk about planning, this activity would not be separated from matters relating to the decision-making process. The process begins with the formulation of the objectives, policies, objectives broadly that evolved on the stage of achieving the goals. Anisah [5] argued that implementation is the activity to realize the plan into action to achieve the stated goal effectively and efficiently. Suyono and Haryanto [6] stated that learning is derived from the word 'to learn' in which it is the activity or process to acquire knowledge, develop skills, improve behavior, attitudes, and reinforce the personality. This notion is more geared to the individual changes, both related to science 
or related to attitude and personality in everyday life. Through this learning process, it hopes that knowledge improved, skills increased, and noble character formed. Suyadi [7] stated that in general the aims of early childhood education are to stimulate the development of children potential to become a faithful, devoted to God the almighty, noble, healthy, knowledgeable, skilled, critical, creative, innovative, independent, confident, becomes democratic and responsible citizens.

Tutor or teacher is a profession as submitted by our President dated on 2 December 2004 in which declared that tutor is a profession. It is emphasized by the law No.14 of 2005 about teachers and lecturers chapter II article 2 states that teachers as professional workers in a formal level for early childhood education. This condition is also reinforced by the recognition of teachers as professionals with certified proof of teacher. Teacher's position as professional worker also serves to enhance dignity and teacher's role as the teaching agent which works to improve the quality of formal and non-formal education Asmawati, [8].

\section{METHODS}

The research used qualitative approach with grounded theory method. The participant were 7 people consist of base informant and source informant. Data collection technique is triangulation data that is combining various data collection techniques and data sources that already exist. The research site located in PAUD Ihya As Sunnah and PAUD Ghifari in Tasikmalaya.

\section{RESULTS AND DISCUSSION}

Implementation Result of Basic Tiered Training based competence by Tutor PAUD in the learning process has been successfully developed developmental aspect, showed positive result. It proves that the basic tiered training they followed could improve learning process of early childhood education.

The implementation of the training fee from the participants because there is no funding from the government and other relevant agencies.

Tutor in PAUD Ihya As Sunnah often uses Beyond Circle and Center method, meanwhile Tutor in PAUD Ghifari uses singing method. In PAUD Ihya As Sunnah the singing method replaced by Al Qur'an Rote. The obstacles that are often perceived in implementing training result is inadequate reward from government.

From the research findings, planning process of basic tiered training held by HIMPAUDI Tasikmalaya formulated in the pre-action process in which the participant followed training process. At first, the committee observed and identified the needs and characteristics of candidates. It did to determine the type of training needs for this basic tiered training that suits for participant who will follow this training process. HIMPAUDI is capable to run the training as effective and efficient so that the goal could be reached easily.

From the research findings, the implementation of basic tiered training included preparation, training implementation, and certification. The method and technique used in this training are lecturing, discussion, question and answer, case study, practice, motivation, energizer, and self-reflection. Technical training for basic tiered training followed the rules and regulations set by directorate of teachers and education personnel (Direktorat GTK).

From the research findings, tutors follow the training assessment. After participants, have completed basic tiered training for 6 days consisting 48 hours of lessons. The materials that were assessed consist of all materials given including 11 materials with 48 hours of lessons and the report of independent task.

From the research findings, the tutors of early childhood education who have followed this basic tiered training understood and implemented the learning strategy whether method, materials, medium and time of learning. They now understand how to create daily and weekly lesson plans.

Early Childhood Tutor could implement the learning strategy in a better and various ways. PAUD Ihya As Sunnah often use beyond circle and center method, different with PAUD Ghifari with its singing method. Singing Learning Method Honig stated that singing has many benefits for the practice of children's education and personnel development because singing: 1) is an enjoyable activity, 2) treating anxiety, 3) a medium to express feelings, 4) building child's confident, 5) persistence child's memory, 6) developing sense of humor, 7) increasing thinking and motoric skills, and 8) increasing attachment in one community.

From the research findings, Early Childhood Tutor conduct the assessment by direct observation along learning process. This is chosen to get a natural scene of children's development. Doing fieldnotes to write all children activities, children's playing stage, and all that happened and run by the children. Recording child's statement, questions (question and answer), all activities written in a daily note. Reading children's worksheet, documenting all the natural children's language into portfolio.

In assessing early childhood education, there are several ways to choose for example: Direct observation Fieldnote and playing stage Writing children's statement, expression, and question Reading their worksheet, documenting all the natural children's language into portfolio for each student Wismiarti, [9].

\section{CONCLUSIONS}

Based on the findings which have been made to obtain the "Implementation result of basic tiered training based competence by early childhood tutor in early childhood learning process ", the benefits produced showed significantly. The implementation of basic tiered training started from planning, implementing, and assessing reached a good result in accordance with Training Guide of 2015. Besides that, the implementation of basic tiered training result based competence by Early Childhood Tutor succeeded developing the aims of development aspect, got positive result proving that basic tiered training they followed could improve early childhood learning process. 


\section{REFERENCES}

[1] Simamora, H. Manajemen Sumber Daya Manusia Edisi Pertama. Yogyakarta: STIE YKPN 1997

[2] Kamil, M. Model pendidikan dan pelatihan (konsep dan aplikasi)Bandung: AFABETA. 2007

[3] Sudjana, H.D. Pendidikan Non Formal, Bandung: Falah Production. 2004.

[4] Sudjana, H.D. Pendidikan Non Formal, Bandung: Falah Production. 2004.

[5] (1995). Pengelolaan Pendidikan Dasar. Bandung: Institut Keguruan Ilmu Pendidikan (IKIP)

[6] Haryanto dan Suyono, . Belajar dan Pembelajaran; Teori dan Konsep Dasar. Bandung : Remaja Rosdakarya 2011

[7] Suyadi, (2013). Teori Pembelajaran Anak Usia Dini dalam kajian Neurosains.Bandung: ROSDA

[8] Asmawati,L. (2014). Perencanaan Pembelajaran PAUD. Bandung: ROSDA

[9] Wismiarti, (2011). Bermain Modul PPOT IV. JakartaTimur : Penerbit Sekolah Al Falah. 